\title{
Genetic Circularity of the Proteus mirabilis Linkage Map
}

\author{
By J. N. COETZEE \\ Department of Microbiology, University of Pretoria, South Africa
}

(Received 9 June 1978)

\begin{abstract}
The $\mathrm{T}$ incompatibility group plasmid R394 can mobilize the chromosome of Proteus mirabilis strain PM5006. It transferred relatively large segments, corresponding to at least 20 min on the D plasmid chromosomal map of the organism. The frequency of recombination for a large number of selected markers was nearly constant at $5 \times 10^{-6}$ per donor cell and it is concluded that mobilization takes place from a number of chromosomal sites. All recombinants were $\mathrm{R}^{+}$and displayed all properties of the plasmid. By analysing crosses for co-inheritance frequencies of unselected markers, a number of chromosomal loci were assembled in linear array. Linkage between markers at the ends of this linkage group was established to markers at the respective termini of the existing D plasmid linkage group. This established a composite circular linkage map of genes of the P. mirabilis strain PM5006 chromosome.
\end{abstract}

\section{INTRODUCTION}

Mobilization of the chromosome of P. mirabilis strain PM5006 by the recombinant plasmid P-lac $\overline{\mathrm{R} 1 d r d 19}$ has been described (Coetzee, 1975). Polarized transfer occurred from an origin near his-1 and involved a gradient of eight markers. As a result of a modification in the conjugation procedure (Coetzee, 1978 a) the linkage map was extended by a further eight chromosomal markers. This plasmid is now named plasmid D (Coetzee, 1978a).

$\mathrm{R}$ plasmid R772 can also mobilize the PM5006 chromosome (Coetzee, 1978b). R772mediated transfer occurred from a number of chromosomal sites and, possibly because predominantly short segments of chromosome were mobilized, co-inheritance of the terminal markers of the D plasmid-derived linkage group could not be demonstrated.

A number of other $\mathrm{R}$ plasmids may mobilize the PM5006 chromosome (J. N. Coetzee and R. W. Hedges, unpublished observations) and the use of one of these, R394 (Coetzee et al., 1972), to establish indirectly the genetic circularity of the PM5006 chromosomal linkage group is described here.

\section{METHODS}

Bacteria and plasmid. These are listed in Table 1.

Media. These were as described previously (Coetzee, 1978b).

Antibacterial drugs. Nalidixic acid, ampicillin, kanamycin, tetracycline (each $50 \mu \mathrm{g} \mathrm{ml}^{-1}$ ) or rifampicin ( $200 \mu \mathrm{g} \mathrm{ml}^{-1}$ ) were added to media when necessary.

Plate matings. These were done by the method of Coetzee (1978a). Briefly, mating mixtures were constituted on non-selective MM (i.e. supplemented with growth requirements of recipient and donor) and incubated overnight before harvesting in saline. Control experiments lacked either donor or recipient. After washing, suitable dilutions were plated on selective MM and incubated for $48 \mathrm{~h}$.

Construction of $P$. mirabilis UP strains containing plasmid R394. The liquid mating technique of Coetzee et al. (1973) was used. Donor J53(R394) was counterselected with tetracycline and transfer of the plasmid was selected with kanamycin or ampicillin. Transfer of the markers of plasmid R394 to various UP strains occurred at frequencies of about $1 \times 10^{-2}$ per donor cell. All donor strains were maintained on nutrient agar 
Table 1. Bacteria and plasmid

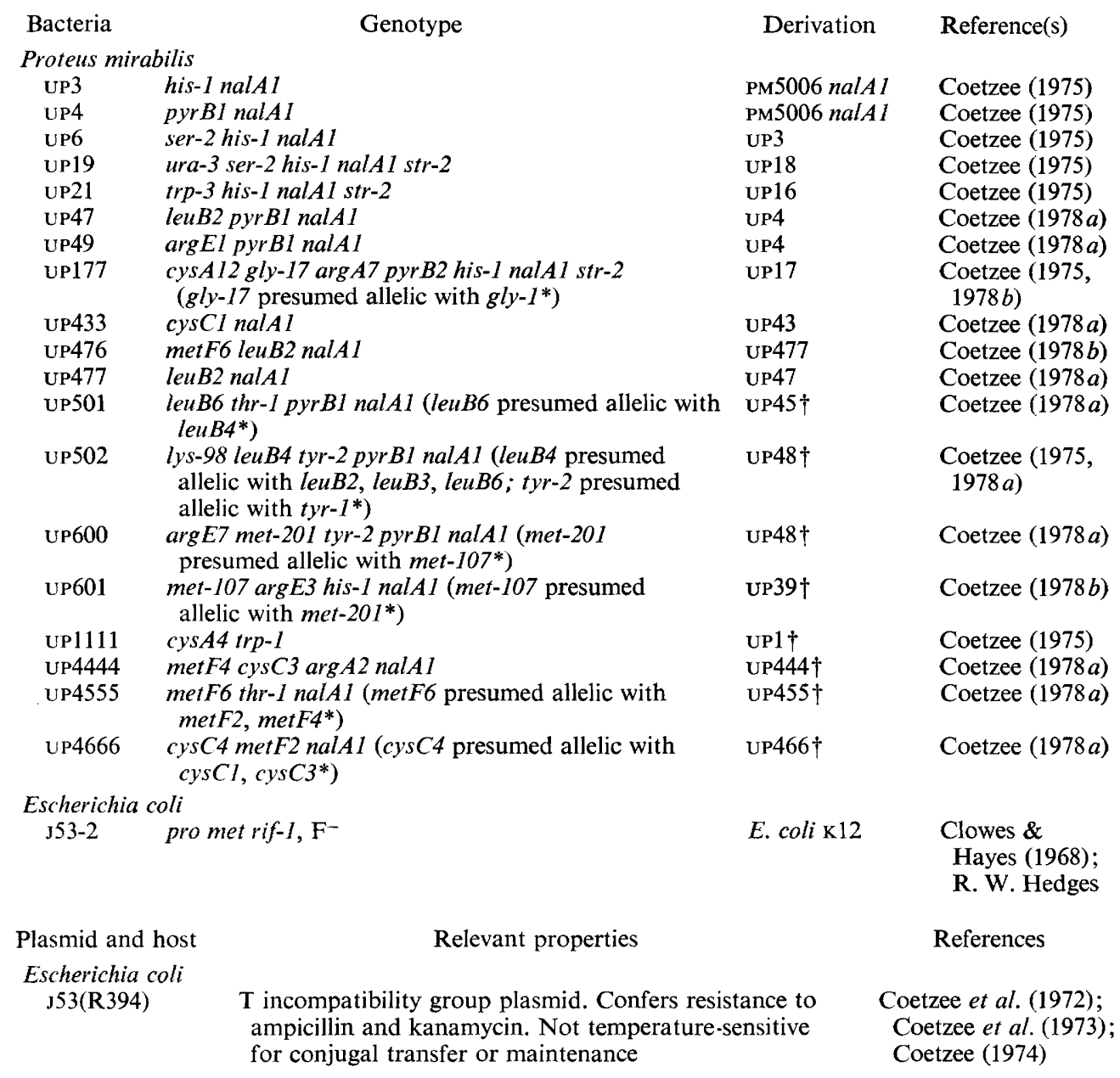

* The mutant strain was transduced (Coetzee et al., 1973) with phage 5006M propagated on the other mutant as well as on wild-type PM5006. Failure to produce prototrophic transductants at normal frequencies with phage reared on the mutant was taken as evidence for presumed allelism.

$+N$-Methyl- $N^{\prime}$-nitro- $N$-nitrosoguanidine-induced mutations (unpublished) in strains previously used (Coetzee, 1978a).

slopes containing ampicillin and kanamycin at $10^{\circ} \mathrm{C}$. They were subcultured at intervals of about 2 months.

Unselected marker analysis and recombinant stability. Recombinant clones were purified on agar similar to that used for selection. Single colonies were then suspended in $0.5 \mathrm{ml}$ saline and loopfuls were spotted on selective media and on the medium used for selection of the particular recombinant. Stability was tested by plating a suitable dilution of an overnight broth culture of a purified recombinant clone on MacConkey agar. After overnight incubation the growth was replicated to selective MM.

$R$ plasmid characterization in chromosomal recombinants. Kanamycin and ampicillin resistance were tested by replication of patched colonies on MM to the same medium containing kanamycin or ampicillin. Ability to transfer kanamycin and ampicillin resistance to J53-2 was tested by the liquid mating technique mentioned above using rifampicin for donor counterselection on MacConkey agar also containing kanamycin or ampicillin. Chromosome donor ability (Haas \& Holloway, 1976) was measured by replication of patched auxotrophic recombinant colonies on suitably supplemented MM to MM recently surface-seeded with recipient UP4. Selection was for pyr $B^{+}$recombinants. 
Table 2. Recombination frequencies of markers using plasmid R394_as donor

Plate matings were done as described in Methods. Selective MM was supplemented, where necessary, with growth requirements for unselected recipient markers.

\begin{tabular}{|c|c|c|c|}
\hline $\begin{array}{l}\text { Selected } \\
\text { marker }\end{array}$ & $\begin{array}{c}\text { Map } \\
\text { location }\end{array}$ & $\begin{array}{l}\text { Recombination } \\
\text { frequency* }\end{array}$ & Cross \\
\hline$h i s-1^{+}$ & $7 \mathrm{~min}$ & $5 \times 10^{-6}$ & 1: UP19 × UP477(R394) \\
\hline pyrB2+ & $18 \mathrm{~min}$ & $4 \times 10^{-6}$ & 2: UP4 × UP3(R394) \\
\hline cys $\mathrm{Cl}^{+}$ & $42 \mathrm{~min}$ & $5 \times 10^{-6}$ & 3: UP433 × UP3(R394) \\
\hline leuB2+ & $\dagger$ & $7 \times 10^{-6}$ & 4: uP47 × uP21(R394) \\
\hline $\arg E 1^{+}$ & $\dagger$ & $4 \times 10^{-6}$ & 5: UP49 × UP21(R394) \\
\hline
\end{tabular}

Table 3. Segregation of unselected markers in crosses

Plate matings were done as described in Methods. Selective MM was supplemented with growth requirements for unselected recipient markers. For each selected marker, the first row of results is for the cross UP $177 \times$ UP476(R394) and the second row is for the cross UP177 $\times$ UP433(R394).

\begin{tabular}{|c|c|c|c|c|c|}
\hline \multirow{2}{*}{$\begin{array}{l}\text { Selected } \\
\text { marker }\end{array}$} & \multicolumn{5}{|c|}{ Co-inheritance of unselected chromosomal markers $(\%)^{*}$} \\
\hline & $h_{i s^{+}}$ & pyrt & cys $^{+}$ & $g l y^{+}$ & $\arg ^{+}$ \\
\hline his- $I^{+}$ & - & $\begin{array}{l}44 \\
54\end{array}$ & $\begin{array}{l}25 \\
28\end{array}$ & $\begin{array}{l}1 \\
0\end{array}$ & $\begin{array}{l}0 \\
0\end{array}$ \\
\hline pyrB2+ & $\begin{array}{l}17 \\
20\end{array}$ & - & $\begin{array}{l}40 \\
28\end{array}$ & $\begin{array}{l}11 \\
15\end{array}$ & $\begin{array}{l}0 \\
0\end{array}$ \\
\hline $\operatorname{cys} A 12^{+}$ & $\begin{array}{l}6 \\
6\end{array}$ & $\begin{array}{l}52 \\
47\end{array}$ & - & $\begin{array}{l}54 \\
64\end{array}$ & $\begin{array}{l}4 \\
2\end{array}$ \\
\hline gly-17+ & $\begin{array}{l}0 \\
0\end{array}$ & $\begin{array}{l}18 \\
24\end{array}$ & $\begin{array}{l}47 \\
54\end{array}$ & - & $\begin{array}{l}7 \\
8\end{array}$ \\
\hline $\arg A 7^{\div}$ & $\begin{array}{l}0 \\
0\end{array}$ & $\begin{array}{l}0 \\
0\end{array}$ & $\begin{array}{l}17 \\
24\end{array}$ & $\begin{array}{l}63 \\
58\end{array}$ & - \\
\hline
\end{tabular}

* One hundred recombinants for each selected marker were tested for the presence of unselected markers by the procedure described in Methods.

\section{RESULTS}

\section{Inheritance of chromosomal markers}

Transfer. With plasmid R394, recombinant recovery frequencies were about $5 \times 10^{-6}$ per donor cell for all markers tested (Table 2). Similar findings were recorded with plasmid R772 (Coetzee, 1978b) and this is what would be expected if R394 had many sites of association with the chromosome. All progeny were stable through many purification cycles on non-selective media and behaved like haploid recombinants (Meade \& Signer, 1977; Beringer et al., 1978).

Segregation of unselected markers. Using the same strains as previously (Coetzee, 1978b) but with R394 replacing R772 in donor cultures, sets of linkage data were obtained (Table 3). Subject to the same reservations about marker time of entry (see Coetzee, 1978b), it is evident that recombinants often inherited lengths of chromosome corresponding to more than 20 min on the D plasmid map. This is in sharp contrast to the potential of R772 where progeny usually inherited only about half that length of chromosome (Coetzee, $1978 b)$.

\section{Chromosome mapping}

Having established that plasmid R394 mobilized longer stretches of chromosome than R772, it was decided to use it to investigate linkage relationships of some new chromosomal markers to loci situated near the termini of the existing linkage group (Coetzee, 1978b). 


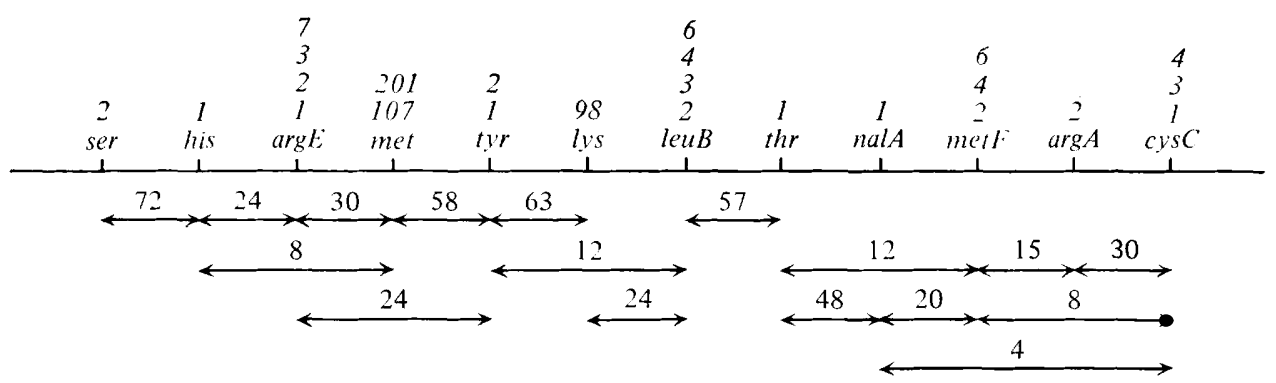

Fig. 1. Linkage map of some markers investigated. Numbers above the markers represent the numbers of presumed alleles. Numbers on the arrows below the linkage map are the percentage co-inheritance frequencies of markers, averaged over two to four crosses. The order of markers on the map was determined on the basis of linkage to other markers. The loci are arbitrarily spaced at equal intervals.

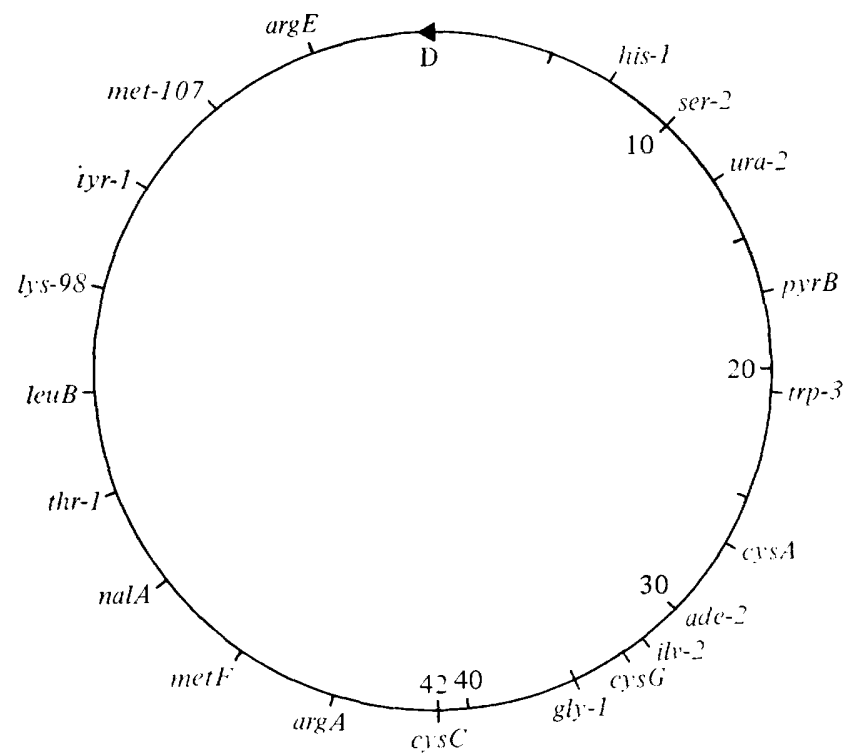

Fig. 2. Circular linkage map of $P$. mirabilis strain PM5006. This map is a composite arrangement of plasmid D-guided chromosome transfer time up to 42 min and plasmid R394-mediated chromosome linkage data based on co-inheritance studies. The loci relating to the latter plasmid are arbitrarily spaced at equal intervals. The transfer origin of plasmid D is designated as 0 min.

Linkage analysis. The relative frequencies of inheritance of different selected markers in the crosses were roughly the same $\left(5 \times 10^{-6}\right.$ per donor) and never varied more than twofold. This indicated that chromosome mobilization occurred from multiple sites and confirmed the results presented in Table 2 .

Crosses were analysed by calculating the percentage co-inheritance frequencies of unselected donor markers with respect to the selected donor locus (Fig. 1). Results of actual crosses are not presented. Although co-inheritance data do not necessarily relate to physical distance between markers (see Beringer et al., 1978), they were used as a measure of linkage between pairs of markers to place the latter in a most probable order (Fig. 1). On this map, loci are arbitrarily spaced at equal intervals (Towner, 1978).

Having thus 'filled the gap' between the ends of the plasmid D-mediated linkage group (Coetzee, 1978a) with linked markers (Fig. 1), it was possible to arrange a single composite circular linkage group (Fig. 2) embracing loci investigated here and previously (Coetzee, $1975,1978 a, b)$. 


\section{Properties of recombinants}

All recombinants were $\mathrm{R}^{+}$and capable of transferring both plasmid markers to J53-2 at frequencies of about $10^{-2}$ per donor cell (not shown).

Five auxotrophic pyr $B^{+}$recombinants from each of eight experiments listed in Table 3 were patch plate-mated to UP4 with selection for $p y r B^{+}$recombinants. UP1111(R394) was used as a control donor. The number of recombinant clones on the patches varied between two and six and similar numbers were found on control areas. The plasmid in chromosomal recombinants thus resembled the wild type in all parameters tested.

\section{DISCUSSION}

$\mathrm{R}$ plasmids may mobilize the bacterial chromosome by associating with one particular region, and transfer of the chromosome then takes place from that single site resulting in a gradient of recovery of gene recombinants amongst suitable recipients (Coetzee, 1975; Towner \& Vivian, 1976; Watson \& Holloway, 1978). Plasmids may also associate with a number of chromosomal sites resulting in the simultaneous transport of many regions of the chromosome (Coetzee, 1978b; Haas \& Holloway, 1976; Beringer et al., 1978). The result is that the polarized gene transfer of any one mobilizing event is scrambled in the population as a whole (Meade \& Signer, 1977).

In attempts to determine genetic circularity of a bacterial chromosome, work with the latter type of plasmid has the disadvantage that direct demonstration of chromosome circularity by time of entry studies is precluded and recourse has to be taken to indirect evidence gathered from mating linkage data (see Watson \& Holloway, 1978). In this study, plate-mating linkage data derived from the use of plasmid R394, which presumably has multiple sites of association with the chromosome (see Table 2), were used to complement gene time of entry results obtained with plasmid D (Coetzee, 1978a) in order to demonstrate genetic circularity of the PM5006 linkage group. Plasmid R772 had failed in this complementing task (Coetzee, 1978 b) but the array of markers used here was not available then. In view of the relatively large chromosomal fragments mobilized by R394 (see Table 3), the present demonstration of genetic circularity could possibly have been done with the use of only the latter plasmid.

By the judicious use of gene time of entry studies involving three plasmids which direct chromosomal transfer from single sites and also plate-mating linkage data, Watson \& Holloway (1978) indirectly proved the genetic circularity of the Pseudomonas aeruginosa strain PAT chromosomal linkage group. Single R plasmids of the multiple chromosomal association type, on the other hand, have been used in plate-mating experiments to derive linkage data which indirectly established circularity of chromosome linkage groups in Rhizobium meliloti (Meade \& Signer, 1977; Kondorosi et al., 1977) and Rhizobium leguminosarum (Beringer et al., 1978).

The establishment of the circularity of the chromosome of PM5006 together with the availability of a number of plasmids capable of mobilizing it (Coetzee, 1978 $a, b ; \mathrm{J} . \mathrm{N}$. Coetzee and R. W. Hedges, unpublished) places this organism in the company of several other members of the family Enterobacteriaceae (see Riley \& Anilionis, 1978). It differs from these in gene arrangement (see Sanderson, 1976; Riley \& Anilionis, 1978; Coetzee, $1978 a$ ) and one task for the future is to elaborate the present gene map.

The author is in receipt of grants from the South African Medical Research Council. 


\section{REFERENCES}

Beringer, J. E., Hoggan, S. A. \& Johnston, A. W. B. (1978). Linkage mapping in Rhizobium leguminosarum by means of $\mathrm{R}$ plasmid-mediated recombination. Journal of General Microbiology 104, 201-207.

Clowes, R. C. \& Hayes, W. (1968). Experiments in Microbial Genetics. Oxford and Edinburgh: Blackwell Scientific Publications.

CoetzeE, J. N. (1974). High frequency transduction of kanamycin resistance in Proteus mirabilis. Journal of General Microbiology 84, 285-296.

Coetzee, J. N. (1975). Chromosome transfer in Proteus mirabilis mediated by a hybrid plasmid. Journal of General Microbiology 86, 133-146.

Coetzee, J. N. (1978a). Extension of a chromosome linkage group of Proteus mirabilis. Journal of General Microbiology 107, 155-163.

Coetzee, J. N. (1978b). Mobilization of the Proteus mirabilis chromosome by $\mathbf{R}$ plasmid $\mathrm{R} 772$. Journal of General Microbiology 108, 103-109.

Coetzee, J. N., Datta, N. \& Hedges, R. W. (1972). $\mathrm{R}$ factors from Proteus rettgeri. Journal of General Microbiology 72, 543-552.

Coetzee, J. N., Datta, N., Hedges, R. W. \& Appelbaum, P. C. (1973). Transduction of R factors in Proteus mirabilis and $P$. rettgeri. Journal of General Microbiology 76, 355-368.
HaAs, D. \& Holloway, B. W. (1976). R factor variants with enhanced sex factor activity in Pseudomonas aeruginosa. Molecular and General Genetics 144, 243-251.

Kondorosi, A., Kiss, G. B., Forrai, T., Vincze, E. \& BANFalvi, Z. (1977). Circular linkage map of Rhizobium meliloti chromosome. Nature, London 268, 525-527.

Meade, H. M. \& Signer, E. R. (1977). Genetic mapping of Rhizobium meliloti. Proceedings of the National Academy of Sciences of the United States of America 74, 2076-2078.

Riley, M. \& ANILIONIS, A. (1978). Evolution of the bacterial genome. Annual Review of Microbiology 32, 519-560.

Sanderson, K. E. (1976). Genetic relatedness in the family Enterobacteriaceae. Annual Review of Microbiology 30, 327-349.

Towner, K.J. (1978). Chromosome mapping in Acinetobacter calcoaceticus. Journal of General Microbiology 104, 175-180.

TOWNER, K. J. \& VIVIAN, A. (1976). RP4 fertility variants in Acinetobacter calcoaceticus. Genetical Research 28, 301-306.

Watson, J. M. \& Holloway, B. W. (1978). Chromosome mapping in Pseudomonas aeruginosa PAT. Journal of Bacteriology 133, 1113-1125. 